\title{
Life Cycle Assessment of External Vertical Closing Systems0: Sealing Masonry vs. Structural Masonry - a Brazilian Case Study
}

Cláudio Henrique Pires e Silva ${ }^{\text {a }}$, Ricardo Augusto dos Santos Horta ${ }^{\text {a }}$, Lineker Max Goulart Coelho ${ }^{\text {a }}$, Raquel Diniz Oliveira ${ }^{\text {a }}$

\author{
a Programa de Pós-Graduação em Engenharia Civil - PPGEC - Centro Federal de Educação Tecnológica de Minas Gerais - \\ Av. Amazonas, 7675, Nova Gameleira, CEP: 30510-000, Belo Horizonte, MG, Brasil. \\ e-mail: claudio_hps@hotmail.com; ricardocivi192@gmail.com; lineker@cefetmg.br; raqueldo@gmail.com
}

\begin{abstract}
The civil construction industry is one of the sectors that most consume natural resources in the world and, consequently, one of that generate more waste. Thinking about constructive techniques that generate less impact on the environment is vital to ensure sustainable development. In this scenario, the Life Cycle Assessment (LCA) has been presented as an internationally recognized approach, that assesses the potential impact of products and services on human health and the environment, throughout its entire life cycle. Aimed to identify construction techniques and vertical closing systems that generate less impact and consumption of natural resources, the impacts generated by the life cycle of the three vertical closing systems most applied in construction sites in Brazil were compared: ceramic brick masonry system $(\mathrm{CBr})$; concrete block masonry system (CBk); and structural blocks masonry system (SBk). The SBk proved to be the least impacting to the "Resource Scarcity", "Damage to Human Health", and "Damage to the diversity of Ecosystems" interesting areas. This performance is directly related to the use of cement CPIII type and also by the fact that the SBk consumes less concrete and mortar than the others. Already the "Water Consumption" area, the CBk was the least impacting due to the lower consumption of electricity during its life cycle. The reliability of the results was proven through a sensitivity analysis of the normalization and characterization factors, which consisted of comparing the results obtained by applying two different methodologies. It is believed that the LCA study carried out can assist in the decision-making process regarding the choice of the most sustainable construction method.
\end{abstract}

Keywords: life cycle assessment, sealing masonry. structural masonry, ceramic bricks, concrete blocks.

\section{INTRODUCTION}

The civil construction industry is one of the sectors that most consume natural resources in the world and, consequently, one that generate more waste. It is estimated that this sector is responsible for the consumption of $40 \%$ of all raw materials in the world, contributing to around $40-50 \%$ of all greenhouse gas emissions and acid rain to the atmosphere (GARCÍA-SEGURA et al, 2014). Over the years, these impacts have resulted in damages to the environment and in climate change, to the point that the quality of life on the planet is threatened. Extreme weather events such as heat waves, storms and floods have increased in intensity and have hit large urban centers quite frequently. Faced with the emergence of the environmental crisis, the civil construction sector is called upon to adapt its production processes to this new paradigm. Thus, thinking about constructive techniques that generate less impact on the environment is vital for ensuring sustainable development.

In this scenario, the Life Cycle Assessment (LCA) has been presented as an internationally recognized approach, that assesses the potential impact of products and services on human health and the environment, throughout its entire life cycle, including the extraction of raw materials, transportation, production, use and final destination (ISO, 2006; KLÜPFFER, 1998). This methodology can be applied to any type of product and decision making in which the environmental impacts of part or all of the life cycle are of interest (CAYS, 2017).

Among the various possibilities, LCA allows to identify opportunities for improving the environmental performance of products at various points in their life cycle, assists in decision making and provides support to the marketing and communication area (BRIBIÁN et al., 2009; RUSSELL-SMITH et al., 2015; SOUSTVERDAGUER et al., 2020). This tool has been more and more used by the civil construction industry to assess and compare the environmental performance of buildings, construction materials and building techniques (BUYLE et al., 2013; CABEZA et al., 2014).

Condeixa et al. (2014) used the LCA methodology to assess the environmental impact of internal walls of a traditional building in Brazil, consisting of ceramic block masonry, settlement mortar, roughcast and plaster. The 
impacts are assessed with the CML2001 method for a cradle-to-grave perspective, with a 50 years building lifespan, including: early stages for building material manufacturing, construction, use/maintenance, demolition, and distribution (transport) from material to site and from waste to landfill. Results showed that lime is the material-component with the largest contribution to impacts, whereas the use phase is the one with the highest associated impact.

Maodus et al. (2016) performed a life cycle and energy performance assessment of three wall types in southeastern Europe region: prefabricated timber-frame, aerated autoclaved concrete and a solid brick wall with two model heating regimes. In order to perform an LCA, SimaPro 8 software was used. The LCIA method chosen was the IMPACT 2002+. Analysis results show that the model with aerated autoclaved concrete wall has the best environmental performance and that model with masonry brick walls has the best thermal performance in discontinuous heating mode of the three analyzed walls. In order to determine the uncertainty of the life cycle calculations regarding the three analyzed models a Monte Carlo analysis with 1000 variations and 95\% confidence interval was performed on required heating and cooling energy data.

Evangelista et. al (2018) quantified the environmental performance of four typical Brazilian residential buildings with different typologies, through the complete Life Cycle Assessment (LCA) from cradle-to-grave. Two impact assessment methods were used: (1) the Cumulative Energy Demand (CED) for the energy impact; and (2) the International Reference Life Cycle Data System (ILCD 2011) midpoint method. The LCA considered eight impact categories, including carbon emissions and energy demand. The analysis included the relative importance of life cycle phases, construction processes and materials that make the largest contributions to the buildings environmental impacts. According to the results, the operational phase is the most critical, the foundation, structure, masonry and coating have the greatest environmental impacts and in terms of materials, concrete, ceramic tiles and steel made the largest contributions.

Soust-Verdaguer et al. (2020) used the LCA associated with BIM to compare the environmental impacts generated over the life cycle of two single-family buildings types: one built in masonry and other in wood. The authors found that the wooden building was less impacting in five of the six impact categories analyzed and that the BIM methodology when associated with LCA can be used as a tool to estimate the impacts of a building still in the design phase.

Mahecha et al. (2020) has made a research work assessing existing trade-offs between precast reinforced concrete panel (RCP) and the conventional constructive system - ceramic block masonry (CBM) - in social housing deployment in Brazil. Dynamic Life Cycle Carbon Assessment (cradle-to-grave), cost analysis and building thermal-energy simulations are applied for 6 Brazilian bioclimatic zones. The LCIA method IMPACT $2002+$ was chosen in this study, with the midpoint indicator of global warming impact. The main findings show that the RCP has lower upfront costs, but worse performance in terms of GHG emissions and total cost (operational costs included), leading to a trade-off between social housing deployment and GHG emissions mitigation.

Life cycle and life cycle cost analysis were used by Ansah et al. (2020) to compare four external vertical closure systems: concrete block and mortar façade, stabilized earth block façade, isolated shotcrete composite façade and isolated composite galvanized steel façade. The analyzes were performed from the perspective of energy consumption total, global warming potential and life cycle cost and indicated the stabilized earth block façade as the most sustainable option.

Souza et al. (2015) compared the environmental impacts associated with the life cycle of ceramic and concrete roof tiles in Brazil. The SimaPro software was used to assess the environmental performance of the coverage systems in five areas of interest: climate change, human health, ecosystem quality, resource depletion and water withdrawal. The authors found that apparently for the Brazilian context, roofs composed of ceramic tiles can be less impacting than roofs made of concrete tiles. The environmental impacts of the life cycle of ceramic brick, concrete block and cast in-place molded reinforced concrete exterior walls were also compared in a second study, for the Brazilian context, in the same areas of interest (Souza et al., 2016). The results indicated that for the areas "climate change", "human health" and "ecosystem quality", the ceramic brick walls produced less impact, while for the areas "resource depletion" and "water withdrawal" the results found were not significant.

Although there are many studies concerning the impacts caused by the life cycle of buildings and by different types of external sealing systems, features like the transport distance, energy matrix, construction method and composition of the materials used can affect the results of an LCA (ANSAH et al., 2020; BUYLE et al., 2013; CABEZA et al., 2014). Thus, it is necessary to carry out more regionalized analyzes that accurately represent the local reality.

In addition, it was found, through bibliographic review, that most comparative studies of masonry systems involving the LCA methodology did not compared the masonry construction units itself (blocks produced with 
different materials for example) neither carried out sensitivity analysis, as this is an optional process within the results interpretation phase. So there is the need for elaborating a more robust study, seeking to evaluate the effect of the variation of the input parameters and the analysis model on the final result of the LCA, thus testing the reliability of the results found.

Based on that, this research work presents a case study of the life cycle of three vertical closure systems applied to a $108 \mathrm{~m}^{2}$ building, located in the city of Belo Horizonte (Minas Gerais, Brazil) i) ceramic brick masonry system $(\mathrm{CBr})$; ii) concrete block masonry system (CBk); and iii) structural blocks masonry system (SBk). The main objective of this study is to identify which of the three vertical closure systems most applied in construction sites in Brazil generate less impact and consumption of natural resources in its life cycle, considering the manufacture, transport and construction stages.

It is believed that this research work be assist in the decision making process in the construction industry, to the showing the less aggressive construction technique from an environmental perspective.

\section{LCA METHODOLOGY}

In this topic, the four LCA phases, guided by the ISO 14040 series, are described:

- Purpose definition and scope - definition of functional units, boundaries of the study, indicators to be used, premises adopted and desired goals;

- Life Cycle Inventory (LCI) - detailed research of the processes, their inputs and outputs;

- Life Cycle Impacts Assessment (LCIA) - application of Impact Assessment Method and calculation of environmental impacts;

- Analysis and interpretation of results - graphical interpretation of the results, including sensitivity analysis.

Secondary data from previous studies and the ELCD database (v.3.2) were used to prepare the life cycle inventory. OpenLCA ${ }^{\circledR}$ software (v.1.10.2) was used during the LCI and LCIA steps to perform the calculations of the inputs and outputs and the indicators generated for the impact categories and protection areas analyzed.

\subsection{Purpose definition and scope}

The present study aimed to evaluate the environmental impacts and the consumption of natural resources in the life cycle of three constructive external vertical closing systems: CBr, CBk and SBk. The processes and subprocesses involved in the manufacturing, transport and use construction components, necessary to seal a two story building (see, Appendix A and B), with $108.26 \mathrm{~m}^{2}$ of built area were considered. The edification has net façade area of $179.58 \mathrm{~m}^{2}$ (discounting openings and gaps) and seven ambiences: one bedroom suite, two bedrooms, two bathrooms, one kitchen and one living room with balcony. It is located in Belo Horizonte (1949'01"S; $43^{\circ} 57^{\prime} 21^{\prime \prime W}$ ), capital of the Minas Gerais state (Brazil) with a territorial area corresponding to $331,401 \mathrm{Km}^{2}$ and a population of about 2.4 million inhabitants (IBGE, 2020).

The three vertical closing systems are composed of blocks with $14 \times 19 \times 39 \mathrm{~cm}$ dimensions and it are laid with mortar of $1 \mathrm{~cm}$ thick. The two masonry sealing systems $(\mathrm{CBr}$ and $\mathrm{CBk})$ are coated on their internal and external faces with a $2.5 \mathrm{~cm}$ layer of mortar and $0.3 \mathrm{~cm}$ of plaster and painting, while the structural blocks masonry system (SBk) it is coated with $2.5 \mathrm{~cm}$ and $1 \mathrm{~cm}$ of mortar on the external and internal faces, respectively, in addition to $0.3 \mathrm{~cm}$ of plaster and painting in both faces. This difference can be explained by the better quality control of the structural blocks, which ensures, in most cases, more regular surfaces, thus allowing the use of thinner coating layers.

Because the masonry sealing systems do not have the capacity to support the structure weight, it was considered that the façade area occupied by beams and pillars corresponds to $54.29 \mathrm{~m}^{2}$, according to the dimensions foreseen in the project (Appendix 1). It was also considered that the shapes used for the execution of the structural elements are metallic and due to the large number of times that they can be reused, their values of inputs and outputs were not included in this analysis.

The calculation of the energy required to manufacture the mortar at the construction site was carried out considering the use of a concrete mixer, with power of $1500 \mathrm{~W}$, capacity of 400 liters and an average mixing time 
of 10 minutes. To calculate the waste material, a percentage loss of 3\% for structural blocks, $5 \%$ for machined concrete and sealing blocks, $10 \%$ for steel and 30\% for mortar was considered (PINI, 2010).

To the input and output flows compatibilization the production of the square meter $\left(\mathrm{m}^{2}\right)$ of external wall was defined as the functional unit. This unit was chosen because it is the same used in other LCA studies of vertical closure systems (CONDEIXA et al., 2014; MERAL et al., 2014; SOUZA et al., 2016). Based on this, the reference flow of the materials was determined (see Table 1):

Table 1 - Functional unit and reference flows.

\begin{tabular}{cccccc}
\hline $\begin{array}{c}\text { Vertical locking system } \\
\left(\mathbf{1} \mathbf{m}^{\mathbf{2}} \text { of external wall) }\right.\end{array}$ & Block (un.) & $\begin{array}{c}\text { Bonding } \\
\text { mortar } \mathbf{( K g})\end{array}$ & Steel (Kg) & $\begin{array}{c}\text { Coating mortar } \\
\mathbf{( K g )}\end{array}$ & $\begin{array}{c}\text { Concrete } \\
\mathbf{( K g})\end{array}$ \\
\hline $\mathrm{CBr}$ & $\begin{array}{c}12.5 \text { (equivalent to } 93.75 \\
\text { kg of ceramic) }\end{array}$ & 25.50 & 3.00 & 123.5 & 101.42 \\
\hline $\mathrm{CBk}$ & $\begin{array}{c}12.5 \text { (equivalent to } \\
116.25 \text { kg of concrete) }\end{array}$ & 25.50 & 3.00 & 123.5 & 101.42 \\
\hline $\mathrm{SBk}$ & $\begin{array}{c}12.5 \text { (equivalent to } \\
146.25 \text { kg of concrete) }\end{array}$ & 25.50 & 1.81 & 86.5 & 45.87 \\
\hline
\end{tabular}

Source: Prepared by the authors, 2020.

In terms of geographical coverage, the study was developed considering the context of the city of Belo Horizonte. Thus, the methodology used in this research can be applied in other areas, but the results and conclusions presented in this study are specific to the region studied. For this study, it was considered that there were no significant changes in the construction techniques and transport modals used as well as in the Brazilian energy matrix, in the next 5 years

\subsection{Life cycle inventory - LCI}

\section{Detailed description of processes and sub-processes}

The LCI referring to the cement manufacturing process was elaborated considering the steps and guidelines defined by, ABCP (2019), which are:

- Crushing: the limestone rock is initially crushed and then triturated in order to obtain particles with dimensions suitable for the industrial process. The extracted clay is milled.

- Deposit: crushed limestone and clay are deposited separately to undergo quality tests and then subjected to a pre-homogenization process.

- Mixing: limestone and clay are mixed in a proportion of $90 \%$ limestone and $10 \%$ clay.

- Flour mill: the mixture of clay and limestone is then milled to obtain particles with a diameter of approximately $0.05 \mathrm{~mm}$.

- Homogenization silos: the milled mixture, now called flour it is then subjected to the homogenization process to obtain the exact amount of elements that will make up the clinker.

- Fusion: the flour burned at about $1450^{\circ} \mathrm{C}$ inside a rotary kiln produces a new material known as clinker, which is presented in the form of dark pellets.

- Cooler: through a cooler, the clinker temperature is then reduced to $80^{\circ} \mathrm{C}$, which marks the end of the clinker production process.

- Mixing: in addition to clinker, plaster, blast furnace slag, pozzolana and limestone are added for the production of Portland cement.

- Additions and milling final: during the clinker milling process, materials such as blast furnace slag, plaster, pozzolanic materials and carbonate materials are added to improve their rheological characteristics and form the cement.

- Storage: the cement is then bagged and stored in piles on pallets for later dispatch.

Regarding the steel making process, the following steps were considered, according to CBCA (2015), CNI (2013), COSTA (2013) e WORLDSTEEL (2012): 
- Sintering and pelletizing: in the sintering process the sinter fell (average granulometry of $1 \mathrm{~mm}$ ) is mechanically mixed with manganese ore, fluxes, fuels, by-products and additives; after homogenization this mixture goes to a conveyor belt where it is burned at $1200^{\circ} \mathrm{C}$. The process of melting the materials gives rise to the crude sinter, a prepared load rich in iron. In turn, the sinter fell is mixed with limestone and binders in a rotary kiln and is subsequently burned, giving rise to the pellet.

- Coke production: coke is primarily responsible for supplying carbon during the steel making process. It is formed by burning the coal mix previously selected in furnaces with a reducing atmosphere, in order to obtain the release of volatile compounds. Then the coke, which now has an average temperature of $1300^{\circ} \mathrm{C}$, leaves the furnace and is sent to cooling towers, where it is cooled through direct contact with water.

- Pig iron production: in this stage the ferrous load (sinter and pellet) together with the coke is taken to blast furnaces where they are deposited in alternating layers of material. When in contact with a mixture of heated air (about $1200^{\circ} \mathrm{C}$ ) and pulverized coal, coke starts the combustion process and it increases the temperature furnace to about $2300^{\circ} \mathrm{C}$. This burning releases carbon monoxide $(\mathrm{CO})$, which in turn binds to the oxygen molecules $(\mathrm{O})$ of iron oxide, leaving the iron free, process known as reduction. After the reduction, the iron, now in a liquid state (pig iron), is then drained, but during this process, impurities such as carbon and phosphorus are incorporated, which results in a compound with a 95\% iron contraction. The pig iron then goes to the steelmaking stage.

- Steelmaking: pig iron in a liquid state is then cooled by injecting oxygen through a refrigerated lance, which causes the oxidation of carbon (formation of $\mathrm{CO}$ ) present in the liquid mixture thus releasing a large amount of heat. The oxygen injection is interrupted when the carbon content in the mixture reaches values below $2 \%$, thus ending the transformation of pig iron into steel. Then the material goes to the lamination.

- Lamination: in this stage the steel in solidification process is mechanically shaped and transformed into sheets, rebars, bars, coils, etc. Afterwards, it is done the descaling and washed and finally it goes on to storage and shipping.

- Steel storage: after its manufacture, the steel is stored without contact with the ground and in covered places and without moisture. Depending on the material type, it is stored on rafters, pallets or shelves.

Regarding the ceramic brick manufacturing process, the LCI included the processes:

- Preparation and Mixing: depending on its hardness and workability the extracted clay is crushed and /or milled to reduce its granulometry and then mixed using mechanical equipment (backhoe) with another clay type, in pre-defined proportions (BACCELI JÚNIOR, 2010). Generally, a "strong" clay with a higher concentration of clay minerals is used (chlorite, illite, smectite, and kaolinite mainly) and another with a higher concentration of silica and lower content of clay minerals, known as weak clay. Then the mixture is conducted to the coffin feeder machine where it is moistened to increase its degree homogenization and proceeds to the disintegrator that grinds the clods formed during feeding. Finally, through a mixer with blades the mixture made of water and clay (strong and weak) is completely homogenized and proceeds to the lamination stage.

- Lamination and Extrusion: during this process the clay mass is initially compacted through rollers to decrease its pore concentration and increase its density, which facilitates the extrusion process and decreases the probability of defects in the ceramic blocks. Then the solid mass goes through belts to the extruder or maromba where, by means of mechanical conformation (passage of the mass under high pressure through the mouthpiece with the shape of the block), pre-defined columns are molded and then cut to the desired (NORTON, 1973).

- Cutting: generally, at the exit of the extruders, cutting machines are coupled, which by means of highly tensioned steel wires, cut the columns to the desired size, giving rise to the raw blocks. These blocks are then transported to drying sheds.

- Drying: in this process, the water used in the manufacture of the raw blocks is dried by means of a natural drying process, in which the blocks can be exposed outdoors or remain in sheds in environments temperature and without incidence of ventilation and sunlight, or through an artificial drying process, in which the parts are exposed to heat or ventilation in a controlled manner. At the end of the drying process, it is ideal that the humidity of the block is been below 5\% (NORTON, 1973). Then the blocks are transported to the furnace. 
- Burning: in the furnace the pieces are burned at a temperature around 750 and $900^{\circ} \mathrm{C}$. During this process occurs the calcination of the blocks and their physico-chemical characteristics improved, how for example, reduction in the amount of pores, increased interaction between the crystals of the structure and the increase in mechanical resistance and dimensional stability (SEBRAE, 2008). The blocks are then cooled and transported to the storage locations.

- Storage: in this step the blocks are visually inspected for verification of the cracks, breaks and other defects that may compromise their use. After the inspection, the blocks are stored on pallets in open or covered places where they remain until commercialization.

For the manufacture of concrete blocks, with or without structural function, the ICV considered the following steps:

- Dosing and mixing: initially the cement and the aggregates (sand, stone powder and gravel) are selected and follow through the conveyor belt to the mixer. Then the water is added in a controlled amount to the mixer to ensure that the mixture is completely homogenized. A different trace is used for each type of block, that is, different proportions of water, cement and aggregates. After the homogenization process is complete, the mixture proceeds to conformation.

- Pressing: after the mixing the dough goes to the vibrating press (pneumatic, mechanical or hydraulic) where it is shaped, that is, the desired shape is given to the blocks.

- Packaging: after the forming of the concrete blocks, they are stacked on wooden pallets and packaged with polypropylene film. Then they are taken by forklifts to the place destined for their cure.

- Curing: in this step, the blocks are usually placed in a steam camera, where the curing occurs most often at $80^{\circ} \mathrm{C}$ and $100 \%$ humidity, for about 12 hours. This curing process accelerates the strength gain of the block and decreases the chances of critical defects that may compromise its performance. After curing, some blocks from each batch are selected and subjected to compressive strength and water absorption tests and have their dimensions checked.

- Storage: in this stage the products are taken by forklift to the storage location, where they remain until the commercialization. To optimize the use of storage space, concrete blocks can be stacked in up to six rows.

\section{Transport of materials to the construction site:}

For the survey of the transport distances of the materials, the average distances of the factories closest to the center of Belo Horizonte were considered, including the round trip routes. In addition, as in most parts of the city there are construction material distribution centers, a minimum distance of $5 \mathrm{~km}$ between these centers and the construction sites was considered, resulting in a total distance of approximately $10 \mathrm{~km}$ (one way and back).

The distances measured for each type of material were obtained using the Google Maps tool and are detailed in Table 2.

Table 2 - Average transport distance of materials from the factory to the construction site (in $\mathrm{km}$ ).

\begin{tabular}{cccccc}
\hline Material & Factory / Distributor & Round trip & $\begin{array}{c}\text { Distributor } / \\
\text { construction site }\end{array}$ & Round trip & Total \\
\hline Cement & 16.8 & 33.6 & 5 & 10 & 43.6 \\
\hline Steel & 68.2 & 136.4 & 5 & 10 & 146.4 \\
\hline Concrete blocks & 13.7 & 27.4 & 5 & 10 & 37.4 \\
\hline Ceramic bricks & 35.1 & 70.2 & 5 & 10 & 80.2 \\
\hline Sand & 0 & 0 & 5 & 10 & 10 \\
\hline Lime & 0 & 0 & 5 & 10 & 10 \\
\hline Concrete & 0 & 0 & 10.6 & 21.2 & 21.2 \\
\hline
\end{tabular}

Source: Google Maps, 2019.

As the transportation of these inputs is usually done by trucks and considering the wide variety of brands and models used by the various factories and distribution centers, the average consumption in $\mathrm{km} / \mathrm{L}$ of the vehicles 
used was estimated according to (NOVO, 2016) and with the vehicle category divisions defined by Resolution No. 396 of the National Traffic Council (CONTRAN, 2011).

The estimate of the amount diesel oil required for the transportation stage of each input was calculated using the following equation and the results are shown in Tables 3, 4 and 5.

Equation:

$$
T C=\frac{T A I * D}{T L * A C}
$$

Where:

$\mathrm{TC}=$ Total consumption;

TAI = Total amount of input;

$\mathrm{D}=$ Distance from the supplier to the final customer (considering round trip);

$\mathrm{TL}=$ Truck load capacity;

$\mathrm{AC}=$ Average fuel consumption.

$\underline{\text { Table } 3 \text { - Transport stage of building materials with ceramic blocks without structural function. }}$

\begin{tabular}{ccccccc}
\hline Material & $\begin{array}{c}\text { Category of } \\
\text { vehicle used }\end{array}$ & $\begin{array}{c}\text { Autonomy } \\
(\mathbf{K m} / \mathbf{L})\end{array}$ & $\begin{array}{c}\text { Load } \\
\text { capacity } \\
\text { (Ton.) }\end{array}$ & $\begin{array}{c}\text { Total } \\
\text { displacement } \\
(\mathbf{K m})\end{array}$ & $\begin{array}{c}\text { Total amount of } \\
\text { input (Ton.) }\end{array}$ & $\begin{array}{c}\text { Total fuel } \\
\text { consumption } \\
\text { (liters) }\end{array}$ \\
\hline Cement & Heavy & 3.4 & 6.0 & 43.6 & 5.2 & 11.2 \\
\hline Steel & Heavy & 3.4 & 14.0 & 146.4 & 0.5 & 1.7 \\
\hline Cerâmic brick & Heavy & 3.4 & 14.0 & 80.2 & 13.2 & 22.3 \\
\hline Sand & Heavy & 3.4 & 6.0 & 10.0 & 15.7 & 7.7 \\
\hline Lime & Heavy & 3.4 & 6.0 & 10.0 & 5.7 & 2.8 \\
\hline Concrete & Heavy & 3.4 & 14.0 & 21.2 & 18.2 & 8.1 \\
\hline
\end{tabular}

Source: Prepared by the authors, 2020.

Table 4 - Transport stage of building materials with concrete blocks without structural function.

\begin{tabular}{ccccccc}
\hline Material & $\begin{array}{c}\text { Category of } \\
\text { vehicle used }\end{array}$ & $\begin{array}{c}\text { Autonomy } \\
(\mathbf{K m} / \mathbf{L})\end{array}$ & $\begin{array}{c}\text { Load } \\
\text { capacity } \\
\text { (Ton.) }\end{array}$ & $\begin{array}{c}\text { Total } \\
\text { displacement } \\
(\mathbf{K m})\end{array}$ & $\begin{array}{c}\text { Total amount of } \\
\text { input (Ton.) }\end{array}$ & $\begin{array}{c}\text { Total fuel } \\
\text { consumption } \\
\text { (liters) }\end{array}$ \\
\hline Cement & Heavy & 3.4 & 6.0 & 43.6 & 5.2 & 11.2 \\
\hline Steel & Heavy & 3.4 & 14.0 & 146.4 & 0.5 & 1.7 \\
\hline Cerâmic brick & Heavy & 3.4 & 14.0 & 37.4 & 16.4 & 12.9 \\
\hline Sand & Heavy & 3.4 & 6.0 & 10.0 & 15.7 & 7.7 \\
\hline Lime & Heavy & 3.4 & 6.0 & 10.0 & 5.7 & 2.8 \\
\hline Concrete & Heavy & 3.4 & 14.0 & 21.2 & 18.2 & 8.1 \\
\hline
\end{tabular}

Source: Prepared by the authors, 2020. 
Table 5 - Transport stage of building materials with structural concrete blocks.

\begin{tabular}{ccccccc}
\hline Material & $\begin{array}{c}\text { Category of } \\
\text { vehicle used }\end{array}$ & $\begin{array}{c}\text { Autonomy } \\
\mathbf{( K m} / \mathbf{L})\end{array}$ & $\begin{array}{c}\text { Load } \\
\text { capacity } \\
(\mathbf{T o n} .)\end{array}$ & $\begin{array}{c}\text { Total } \\
\text { displacement } \\
\mathbf{( K m )}\end{array}$ & $\begin{array}{c}\text { Total amount of } \\
\text { input } \mathbf{K g})\end{array}$ & $\begin{array}{c}\text { Total fuel } \\
\text { consumption } \\
\text { (liters) }\end{array}$ \\
\hline Cement & Heavy & 3.4 & 6.0 & 43.6 & 3.9 & 8.4 \\
\hline Steel & Heavy & 3.4 & 14.0 & 146.4 & 0.3 & 1.0 \\
\hline Cerâmic brick & Heavy & 3.4 & 14.0 & 37.4 & 27.0 & 21.3 \\
\hline Sand & Heavy & 3.4 & 6.0 & 10.0 & 11.8 & 5.8 \\
\hline Lime & Heavy & 3.4 & 6.0 & 10.0 & 4.3 & 2.1 \\
\hline Concrete & Heavy & 3.4 & 14.0 & 21.2 & 7.5 & 4.7 \\
\hline
\end{tabular}

Source: Prepared by the authors, 2020.

The internal transport of materials within the factories was disregarded in this study, due to the lack of sufficient quantitative data in the bibliography and the transport of materials within the construction site carried out, when necessary, by means of a wheelbarrow.

\section{Premises adopted for LCI of wall construction:}

Below, are presented the considerations involving the procedures for walls building for each system type used to the preparation of the LCI.

First, the process adopted for the construction of the square meter of wall with sealing masonry (ceramic bricks or concrete blocks) according to NBR 8545 (ABNT, 1984) will be described:

- Structure execution: in this stage the beams, pillars and slab are executed which will have the objective of supporting all the building loads, thus ensuring that the masonry plays only the role of vertical sealing system.

- Masonry marking: initially the cleaning of the place where the masonry will be carried out is done, as well as the masonry alignment marking and height definition of each row. Then the devices that attach the masonry to the structure (hair iron anchored to the pillar or welded mesh screwed to the pillar) are attached and the place where the first brick layers will be laid is wetted. Finally, the first blocks layers is installed, starting with the end blocks towards the intermediaries.

- Masonry elevation: after the marking, the masonry it is elevated, that is, the remaining layers are executed, wherein the even rows (2nd, 4th, 6th...) must be started with half a block, so that the lashing of the wall be guaranteed. The horizontal and vertical joints must be about thick of one centimeter; the alignment, plumb and wall level must be checked for each row.

- Wedging: in the region where the masonry will meet the beam, the wall wedged is realized by laying solid blocks at $45^{\circ}$ or using expansive mortar.

Coating: the raised wall receives the coating mortar and then the finish in acrylic paint.

Regarding the construction of a square meter $\left(\mathrm{m}^{2}\right)$ of wall with structural concrete blocks, the following steps were considered, according to NBR 15961-2 (2011):

- Masonry marking: initially the cleaning of the place where the masonry will be carried out is done; then, the place where the first brick layers will be laid is marked as well as the position of steel rebars. The demarcated site is wetted and the end blocks and intermediate blocks are installed. Finally, when the first row is finished, the level, plumb and alignment are checked.

- Masonry elevation: after marking, the remaining rows are executed according to the project. The horizontal and vertical joints must be about one centimeter of thickness; the alignment, plumb and wall level must be checked for each row.

- Steel mooring: once the masonry has finished, channels are laid and filled with steel to ensure the mooring of the all structure. 
- Concreting: after the installation of all the hardware and spacers to ensure its correct positioning the blocks are concreted, which ensures the union of the hardware with the masonry and the increased resistance to compression of the wall.

- Coating: the raised wall receives the coating mortar and then the finish in acrylic paint. Due to the greater regularity of the surface of this wall type, the internal covering layer may be thinner.

\section{Evaluation of alternative uses for the outputs:}

As a way of expanding the boundaries of the analyzed systems, the following strategies were defined for the reuse of some outputs: reuse of scrap from the cutting of steel rebars at the level of $30 \%$ of the metallic loading, a limit established according to the thermal input required for the fusion (CAMILLO, 2016); use of CP-III cement type, with a reuse of slag at the level of $70 \%$ by mass, a value close to the limit allowed by the standard (ABNT NBR 16697, 2018); and finally, like most of the rubble generated by the construction, it is mainly composed of concrete remains, mortar, bricks and blocks (DING; XIAO, 2014;VILVENTHAN; RAM; SUGUMARAN, 2019), it was considered a percentage of $20 \%$ replacement of aggregates by construction waste for the production of blocks and mortars. These alternative uses for the outputs are shown in Fig. 1:

Fig. 1. - On the left reuse of residues from the manufacturing process of walls with concrete block and on the right with ceramic brick.
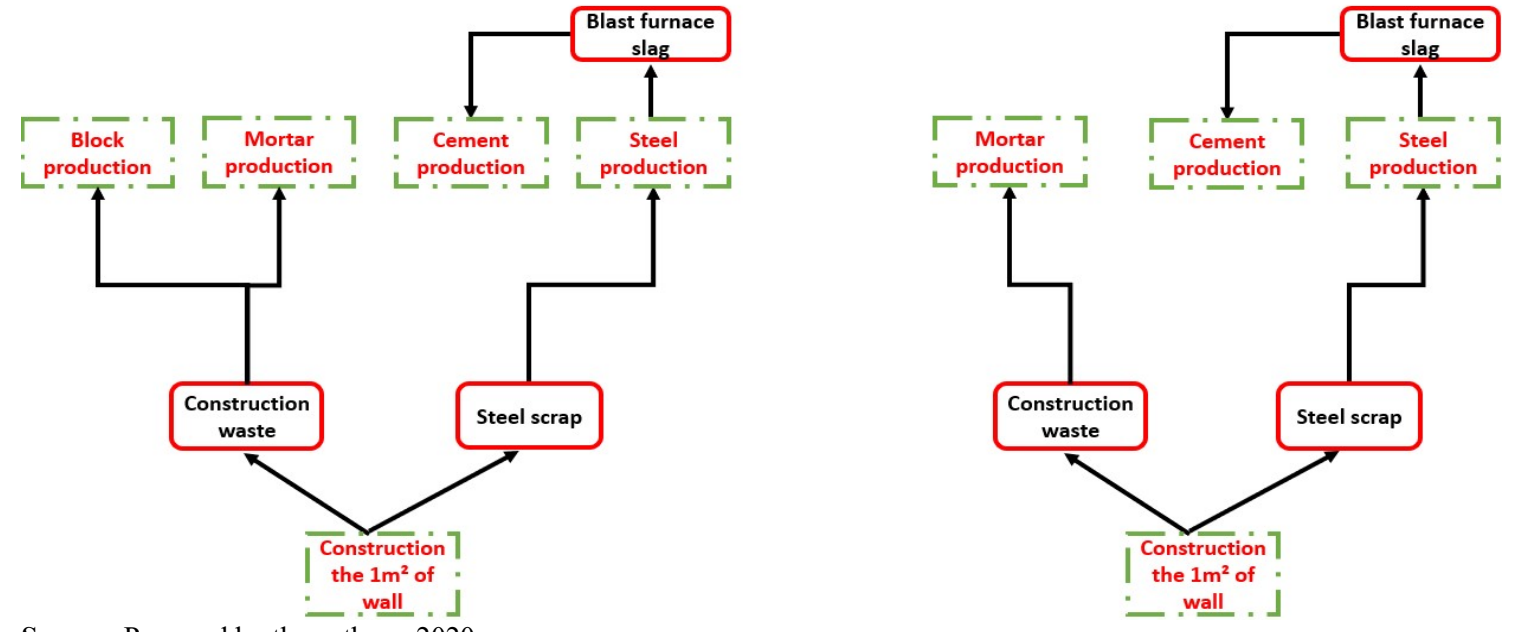

Source: Prepared by the authors, 2020.

\subsection{Life cycle impact assessment - LCIA}

The calculations for transforming the mass and energy balances of the LCI in quantitative impacts on the environmental categories were performed based on the ReCiPe 2016 methodology. This methodology has an approach oriented to both the problem (midpoint) and the damage (endpoint) and includes analyzes from the perspective of 18 impact categories. However, as in this study, the category of fossil scarcity resources showed the zero value, thus only 17 categories were considered (Table 6). Details on the ReCiPe2016 methodology are presented in Huijbregts et al. (2017) .

Table 6 - Impact categories adopted, acronym and corresponding scientific units.

\begin{tabular}{cccc}
\hline Id & Impact category & Acronym & Unity \\
\hline 1 & Fine particulate matter formation & FPM & $\mathrm{kg} \mathrm{PM} 2.5$ eq \\
\hline 2 & Freshwater ecotoxicity & FEC & $\mathrm{kg} \mathrm{1,4-DCB}$ \\
\hline 3 & Freshwater eutrophication & FEU & $\mathrm{kg} \mathrm{P}$ eq \\
\hline 4 & Global warming & GW & $\mathrm{kg} \mathrm{CO} 2$ eq \\
\hline 5 & Human carcinogenic toxicity & HCT & $\mathrm{kg} 1,4-\mathrm{DCB}$ \\
\hline
\end{tabular}




\begin{tabular}{cccc}
\hline 6 & Human non-carcinogenic toxicity & HNCT & $\mathrm{kg} \mathrm{1,4-DCB}$ \\
\hline 7 & Ionizing radiation & IR & $\mathrm{kBq}$ Co-60 eq \\
\hline 8 & Land use & LU & $\mathrm{m} 2 \mathrm{a}$ crop eq \\
\hline 9 & Marine ecotoxicity & MEC & $\mathrm{kg} \mathrm{1,4-DCB}$ \\
\hline 10 & Marine eutrophication & MEU & $\mathrm{kg} \mathrm{N}$ eq \\
\hline 11 & Mineral resource scarcity & MRS & $\mathrm{kg} \mathrm{Cu} \mathrm{eq}$ \\
\hline 12 & Ozone formation, Human health & OFH & $\mathrm{kg} \mathrm{NOx} \mathrm{eq}$ \\
\hline 13 & Ozone formation, Terrestrial ecosystems & OFT & $\mathrm{kg} \mathrm{NOx} \mathrm{eq}$ \\
\hline 14 & Stratospheric ozone depletion & SOD & $\mathrm{kg} \mathrm{CFC11} \mathrm{eq}$ \\
\hline 15 & Terrestrial acidification & TA & $\mathrm{kg} \mathrm{SO2} \mathrm{eq}$ \\
\hline 16 & Terrestrial ecotoxicity & TEC & $\mathrm{kg} \mathrm{1,4-DCB}$ \\
\hline
\end{tabular}

Source: Prepared by the authors, 2020.

To assess the impacts caused to the environment and to compare scenarios, these 17 impact categories were grouped into four major interesses areas: "Resource Scarcity", "Damage to Human Health", and "Damage to the diversity of Ecosystems" and "Water Consumption".

To do this, initially all units of measurement of the impact categories were converted into global impact indices by means of normalization factors used in the ReCiPe 2016 methodology. Then, the data were linked to the interesses areas and then the comparison of the values obtained was made, for each scenario: $\mathrm{CBr}, \mathrm{CBk}$ and $\mathrm{SBk}$.

\subsection{Interpretation of results}

In this step, the results obtained in the previous phases were analyzed in order to answer the proposed objectives. As the inventory data and the characterization and normalization factors used in the life cycle assessment (LCA) contain considerable uncertainty, the sensitivity of the applied methodology was analyzed, through the graphic comparison between the results obtained by its application and the results obtained by applying the ILCD 2011 Midpoint + methodology (WOLF et al., 2012).

As some of the impact categories considered in both methodologies did not have equal units of measurement, only six categories could be compared: "Global Warming", "Stratospheric Ozone Depletion", "Marine Eutrophication", "Freshwater Eutrophication", "Fine Particulate Matter Formation" and "Water Consumption". The results found are presented in item 3.3.

\section{RESULTS AND DISCUSSION}

\subsection{LCI phase}

In this step, all input and output flows involved in the manufacturing process of the $\mathrm{CBr}, \mathrm{CBk}$ and $\mathrm{SBr}$ were analyzed. Approximately 95 inflows and 435 outflows involved in production of each sealing system type have been identified.

As seen in Tables 7 and 8, the $\mathrm{CBr}$ and SBk showed higher values of water input and turbine water release, which directly impacted the amount of liquid effluent released by these systems. This fact may be explained to the higher consumption of electrical energy during the production stages of these systems and to the fact that this energy be supplied mainly by hydroelectric. Additionally, it can be noted that atmospheric emissions, as well as the generation of residues from the life cycle of structural masonry were the lowest among the systems analyzed.. 
Table 7 - Main inputs and outputs of the vertical sealing systems in tons.

\begin{tabular}{cccccccc}
\hline INPUTS & $\mathbf{C B r}$ & $\mathbf{C B k}$ & $\mathbf{S B k}$ & OUTPUTS & CBr & CBk & SBk \\
\hline Water & $10,351.87$ & $7,564.42$ & $9,898.24$ & Turbined water & $10,327.75$ & $7,535.06$ & $9,803.48$ \\
\hline $\begin{array}{c}\text { Aggregate } \\
\text { natural }\end{array}$ & 36.46 & 48.49 & 46.33 & Water vapor & 29.79 & 41.46 & 38.32 \\
\hline $\begin{array}{c}\text { Calcium } \\
\text { carbonate }\end{array}$ & 14.43 & 21.57 & 18.15 & Construction waste & 8.50 & 5.60 & 1.66 \\
\hline Clay & 11.80 & - & & Carbon dioxide & 6.33 & 3.85 & 2.95 \\
\hline Soil & 9.75 & 13.56 & 12.58 & Spoil & 3.36 & 4.45 & 4.26 \\
\hline $\begin{array}{c}\text { Metamorphous } \\
\text { rock }\end{array}$ & 2.44 & 3.15 & 2.53 & Slag & 0.48 & 0.76 & 0.65 \\
\hline
\end{tabular}

Source: Results generated in the Open LCA Software, 2020.

Table 8 - Total waste generated in tons.

\begin{tabular}{lccc}
\hline SVV & Atmospheric emissions (ton.) & Solid waste (ton.) & Liquid effluents (ton.) \\
\hline $\mathrm{CBr}$ & $8.49^{*}$ & 13.07 & $10,327.86$ \\
\hline $\mathrm{CBk}$ & $6.14^{*}$ & 11.68 & $7,535.71$ \\
\hline $\mathrm{SBk}$ & $5.36^{*}$ & 7.27 & $9,803.60$ \\
\hline
\end{tabular}

* The water vapor output was not considered for the calculation of atmospheric emissions.

Fonte: Results generated in the Open LCA Software, 2020.

The total amount of land used in the sub-processes of each analyzed masonry system is shown in Table 9:

Table 9 - Land Use

\begin{tabular}{ccc}
\hline Material & Location & Area $\left(\mathbf{m}^{\mathbf{2}}\right)$ \\
\hline Cement & CRH de Santa Luzia - MG & 6,4171 \\
\hline Steel & Gerdau Aços Longos de Sete Lagoas - MG & 530,277 \\
\hline Concrete & Supermix Concreto de Belo Horizonte - MG & 32,608 \\
\hline Ceramic brick & Milheiro Tijolo - Cerâmica Paraju - MG & 32,893 \\
\hline $\begin{array}{c}\text { Concrete block (fence) } \\
\text { Concrete block (structural) }\end{array}$ & Blocos Solimões - MG & 4,169 \\
\hline 2-story house & Belo Horizonte Central Region & 54 \\
\hline
\end{tabular}

Source: Google Earth, 2020.

\subsection{LCIA phase}

Three vertical sealing system types were assessed in this study. The comparison of the impacts generated by the studied scenarios showed that, in general, the structural masonry system causes less environmental impacts in the midpoint indicators than the ceramic brick and concrete block systems (Table 10 and Fig 2). This is due to the lower consumption of concrete and mortar of the structural system when compared to the other two, given that these two inputs were the main responsible for the consumption of cement. In addition, the use of CPIII cement type, replacing $70 \%$ of the clinker with slag, significantly reduced the impacts caused during the cement production phase. This fact made the producing concrete blocks process less impacting than the producing ceramic blocks process. In addition, due to the greater regularity of the surface of the structural masonry, the internal covering layer could be thinner, which enabled the lower consumption of cement in the coating mortar. 
Table 10 - Result of the LCIA phase: comparison between scenarios

\begin{tabular}{cccccccc}
\hline CI Impacto & $\mathbf{C B r}$ & $\mathbf{C B k}$ & $\mathbf{S B k}$ & $\mathbf{C I}$ Impacto & $\mathbf{C B r}$ & $\mathbf{C B k}$ & SBk \\
\hline FPM & $2.41 \mathrm{E}+00$ & $2.87 \mathrm{E}+00$ & $2.24 \mathrm{E}+00$ & OFH & $1.55 \mathrm{E}-01$ & $1.82 \mathrm{E}-01$ & $1.43 \mathrm{E}-01$ \\
\hline FEC & $1.72 \mathrm{E}-01$ & $1.88 \mathrm{E}-01$ & $1.33 \mathrm{E}-01$ & MEU & $1.64 \mathrm{E}-02$ & $1.73 \mathrm{E}-02$ & $1.23 \mathrm{E}-02$ \\
\hline FEU & $3.21 \mathrm{E}-03$ & $3.24 \mathrm{E}-03$ & $2.08 \mathrm{E}-03$ & MRS & $1.15 \mathrm{E}+01$ & $1.25 \mathrm{E}+01$ & $8.57 \mathrm{E}+00$ \\
\hline GW & $6.43 \mathrm{E}+03$ & $3.96 \mathrm{E}+03$ & $3.04 \mathrm{E}+03$ & OFT & $2.50 \mathrm{E}-01$ & $2.92 \mathrm{E}-01$ & $2.30 \mathrm{E}-01$ \\
\hline HCT & $2.26 \mathrm{E}-01$ & $2.87 \mathrm{E}-01$ & $2.35 \mathrm{E}-01$ & SOD & $6.04 \mathrm{E}-04$ & $7.16 \mathrm{E}-04$ & $5.44 \mathrm{E}-04$ \\
\hline HNCT & $1.23 \mathrm{E}+02$ & $1.25 \mathrm{E}+02$ & $8.65 \mathrm{E}+01$ & TA & $7.80 \mathrm{E}+00$ & $9.29 \mathrm{E}+00$ & $7.23 \mathrm{E}+00$ \\
\hline IR & $3.91 \mathrm{E}+01$ & $5.44 \mathrm{E}+01$ & $4.55 \mathrm{E}+01$ & TE & $1.67 \mathrm{E}+03$ & $1.76 \mathrm{E}+03$ & $1.16 \mathrm{E}+03$ \\
\hline LU & $1.05 \mathrm{E}+01$ & $1.06 \mathrm{E}+01$ & $1.27 \mathrm{E}+01$ & WC & $1.03 \mathrm{E}+04$ & $7.53 \mathrm{E}+03$ & $9.80 \mathrm{E}+03$ \\
\hline MEC & $1.55 \mathrm{E}+00$ & $1.58 \mathrm{E}+00$ & $1.08 \mathrm{E}+00$ & & & & \\
\hline Source
\end{tabular}

Source: Results generated in the Open LCA Software, 2020.

Fig. 2 - Result of the LCIA phase: relative comparison between scenarios

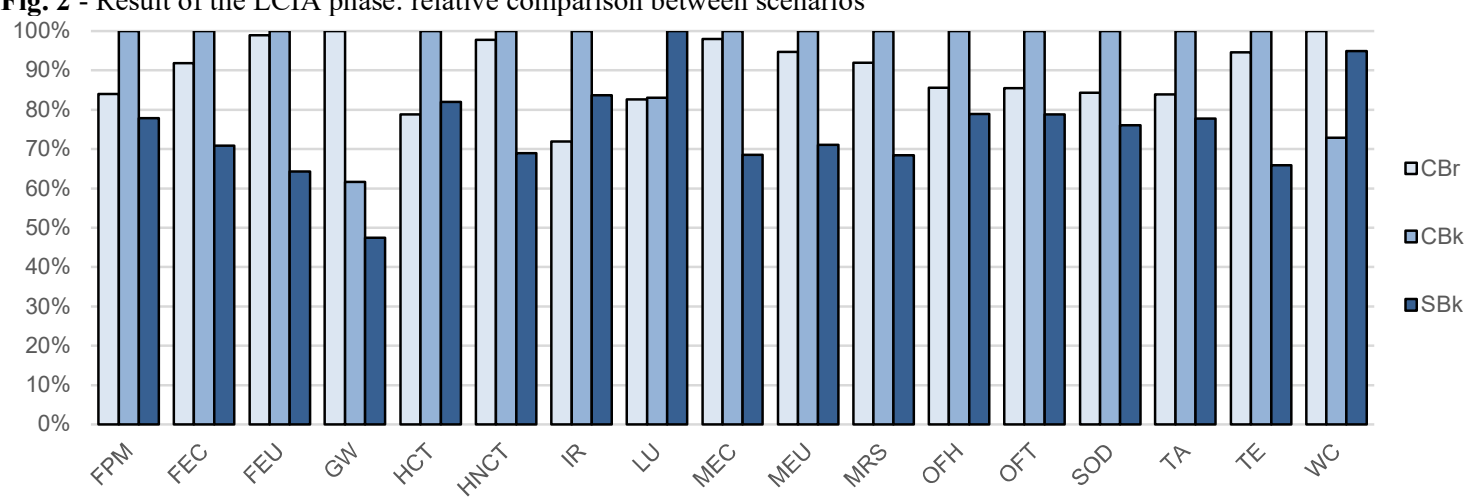

Source: Results generated in the Open LCA Software, 2020.

For the three scenarios analyzed, the steel production stage was the main responsible for the emissions related to the impact categories "Marine Ecotoxicity", "Freshwater ecotoxicity", "Terrestrial ecotoxicity", "Freshwater Eutrophication" and "Marine Eutrophication". For this reason, as the SBk used less steel than the other two systems, its impact value for these indicators was up to $35 \%$ lower. The release of heavy materials such as zinc and mercury into the air and water contributed to almost $70 \%$ of the impacts caused by the "Marine Ecotoxicity" and "Terrestrial Ecotoxicity" categories.

In the "Freshwater Eutrophication" category, the phosphate liberation for water was the main cause of impacts, while for "Marine Eutrophication" the ammonia and nitrogen had greater relevance. Such substances, when in excess in water, favor the multiplication of algae, and consequently the lower availability of light for plants located at the bottom of the body of water, thus reducing photosynthetic rates and the oxygen content available for aquatic species. Although the emission of heavy metals during the production of steel contributed more significantly to the category "Freshwater Ecotoxicity" (approximately 52\% of the impacts generated) the release of decane and zinc to the water during the cement production process was also quite representative for this impact category, representing around $19 \%$ of total emissions.

Due to the similarity of the sealing and structural systems, the main processes that caused impacts to the category "Scarcity of Mineral Resources" were the same in all scenarios. The high consumption of iron and zinc during the production of steel and the consumption of titanium, iron and clay from the cement production process were the main responsible for the impacts caused to this category. Thus, the differences between the results of each system for this category are explained by the higher consumption of steel and mortar in non-structural systems, which justifies the fact that the CBk system has presented the worst performance in this category.

Regarding "Fine Particulate Matter Formation", emissions of sulfur dioxide, nitrogen dioxide and particles less than $2.5 \mu \mathrm{m}$ caused by the burning of fossil fuels, limestone crushing processes and bagging during cement production were the main sources of environmental load. In addition, non-methane volatile organic compounds and methane are released during these processes, which in the case of this study directly influenced the emissions recorded for the "Ozone Formation" and "Stratospheric Ozone Depletion" categories, respectively. As the 
production of mortar and concrete was the main responsible for the demand for cement for all systems, the SBk option registered lower emission values of particulate material.

The large amount of $\mathrm{CO}_{2}$ generated during the cement production and ceramic blocks production processes was mainly responsible for the impact values elevation of the "Global Warming" category. However, as during the concrete blocks manufacturing process, CPIII cement type was used, the impacts generated by $\mathrm{CBr}$ for this category were $53 \%$ higher than those generated by SBk systems and $38 \%$ higher than CBk.

The use of diesel oil during the production of concrete blocks and ceramic bricks was identified as the main responsible for the indicators of the land use category. This category takes into account the space occupied by oil production plants. Thus, as the structural system consumed more fuel, its impact indicators for this category were $18 \%$ higher than the other systems.

Due to the proximity of the Belo Horizonte-MG city with the places of production of the inputs and also, due to the fact that the stages of transportation of raw materials to the factories, as well as the transportation of waste to disposal sites were not considered, the stage of transport was not significant for any of the impact categories analyzed.

Regarding the impacts generated in the interest areas, the normalization of the data and subsequent aggregation of the impact categories allowed us to verify that the SBk system was also the one that showed less damage in three of the four protection areas studied, proving its better performance, when compared to the other two systems (Fig. 3).

Fig.3 - Comparison of protection areas

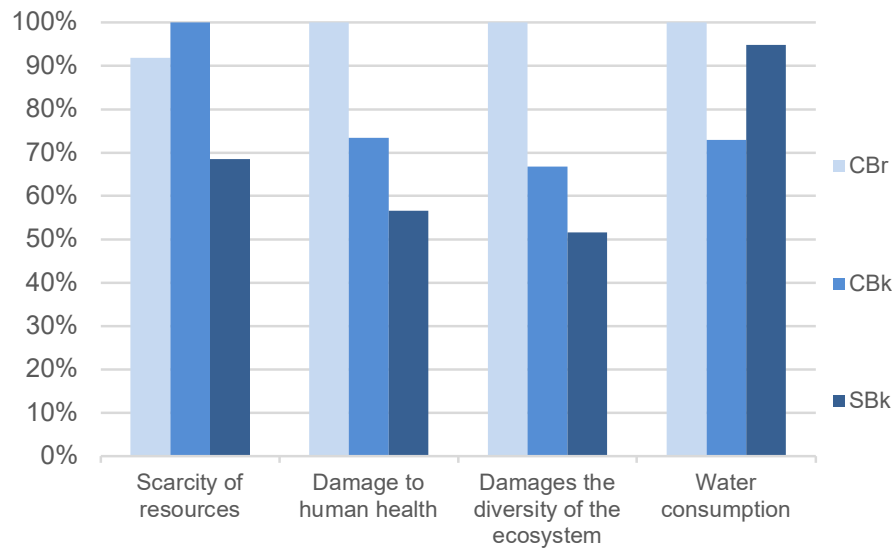

Source: Results generated in the Open LCA Software, 2020

The results for the "Water Consumption" area indicated that the life cycle of the CBk produces lesser impacts compared to the SBk and $\mathrm{CBr}$ scenarios. However, the main output that influences this area is the turbinated water from the process of generating energy in hydroelectric.

Due to the similarity between the execution of the evaluated systems, the impact categories that most influenced the global impact index of all interest areas were the same for the three scenarios. In the area of "Resource Scarcity", the "Mineral Resource Scarcity" category was responsible for $100 \%$ of the impact index for the three scenarios (Fig. 4a). As the iron used for the production of steel bars and the titanium, iron and clay used for the production cement was the main responsible for this result, the systems that used more steel and cement in its composition ( $\mathrm{CBr}$ and $\mathrm{CBk}$ ) were more harmful for this interest area. The impacts generated by steel and cement production processes represent about $62 \%$ and $36 \%, 53$ and $35 \%, 46$ and $39 \%$ of the total impacts generated in this area of interest by the $\mathrm{CBr}, \mathrm{CBk}$ and $\mathrm{SBk}$ systems, respectively.

For the areas of "Damage to Human Health" (Fig. 4b) and "Damage to the Diversity of Ecosystems" (Fig. 4c), the category of global warming impact was the main responsible for its indicators. This fact is directly linked to high $\mathrm{CO}_{2}$ emissions during the ceramic brick production and cement production processes. In addition, emissions of sulfur dioxide and nitrogen dioxide from the cement production process were mainly responsible for the emission of "Fine Particulate Matter" and directly influenced the impacts caused in the area of "Damage to Human Health". 
Fig.4 - Influence of impact categories on protection areas.

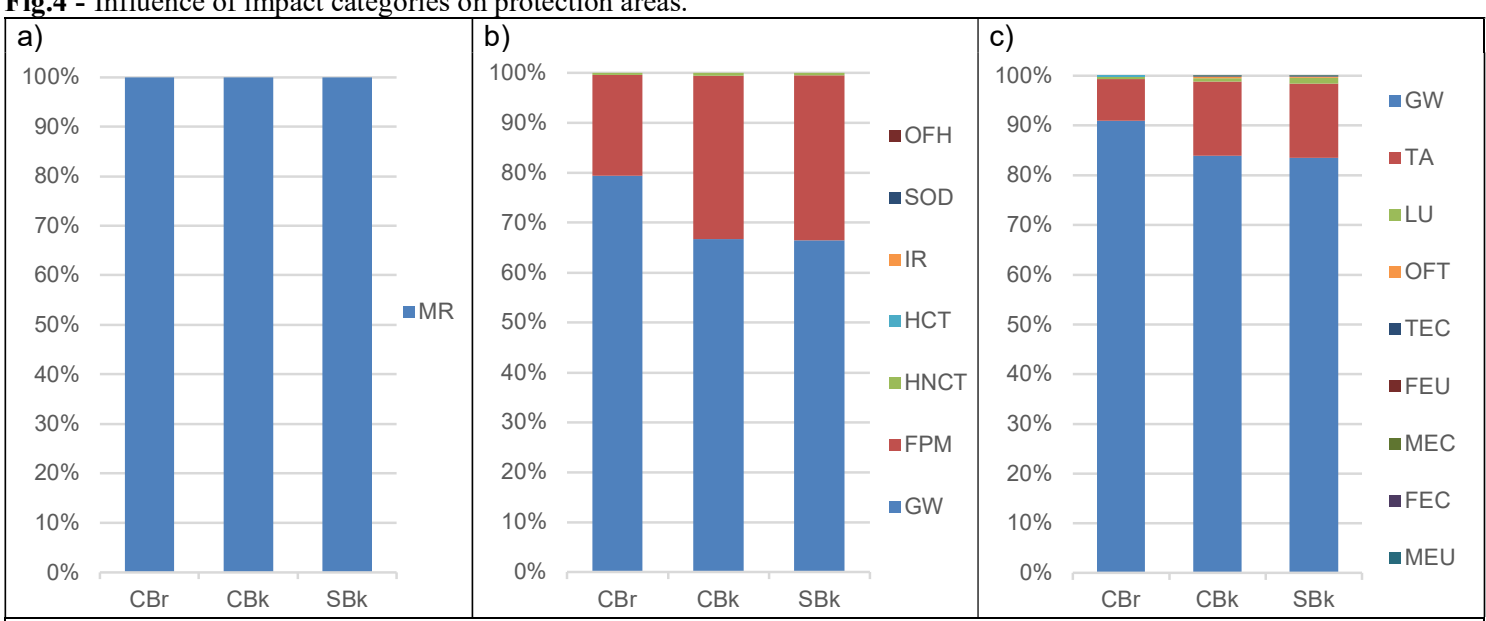

a) Resources Scarcity; b) Damage to human helf; c) Damage the diversity of the ecosystem;

Source: Results generated in the Open LCA Software, 2020.

However, despite the results showing the SBk system as the least impacting, this result could be different if it were considered a scenario where common Portland cement was used, or a larger built area.

\subsection{Study sensitivity analysis}

\subsubsection{Characterization Factors}

The comparison between the indexes obtained for each scenario using the RECIPE and ILCD 2011 methodologies are presented in Tabel 11, and allowed us to verify that although the categories "Stratospheric Ozone Depletion", "Global Warming", "Marine Eutrophication", "Freshwater Eutrophication", "Fine Particulate Matter Formation" and "Water Consumption" does not have the same results, both methods led to the same conclusion: the SBk system is the less aggressive to the impact categories analyzed. This result indicates that the characterization factors used does not influence in the final result of the LCA.

Table 11 - Sensitivity analysis of the methodology characterization factor

\begin{tabular}{lccccccc}
\hline \multirow{2}{*}{ Impact category } & \multirow{2}{*}{ Unit } & $\begin{array}{c}\text { RECIPE- } \\
\text { CBr }\end{array}$ & $\begin{array}{c}\text { ILCD - } \\
\text { CBr }\end{array}$ & $\begin{array}{c}\text { RECIPE- } \\
\text { CBk }\end{array}$ & $\begin{array}{c}\text { ILCD - } \\
\text { CBk }\end{array}$ & $\begin{array}{c}\text { RECIPE- } \\
\text { SBk }\end{array}$ & $\begin{array}{c}\text { ILCD - } \\
\text { SBk }\end{array}$ \\
\hline Stratospheric ozone depletion & $\mathrm{kg} \mathrm{CFC11} \mathrm{eq}$ & $6.04 \mathrm{E}-04$ & $1.53 \mathrm{E}-04$ & $7.16 \mathrm{E}-04$ & $2.01 \mathrm{E}-04$ & $5.44 \mathrm{E}-04$ & $1.63 \mathrm{E}-04$ \\
\hline Global warming & $\mathrm{kg} \mathrm{CO} 2 \mathrm{eq}$ & $6.43 \mathrm{E}+03$ & $6.39 \mathrm{E}+03$ & $3.96 \mathrm{E}+03$ & $3.92 \mathrm{E}+03$ & $3.04 \mathrm{E}+03$ & $3.01 \mathrm{E}+03$ \\
\hline Marine eutrophication & $\mathrm{kg} \mathrm{N}$ eq & $1.64 \mathrm{E}-02$ & $2.93 \mathrm{E}+00$ & $1.73 \mathrm{E}-02$ & $3.32 \mathrm{E}+00$ & $1.23 \mathrm{E}-02$ & $2.58 \mathrm{E}+00$ \\
\hline Freshwater eutrophication & $\mathrm{kg} \mathrm{P}$ eq & $3.21 \mathrm{E}-03$ & $4.18 \mathrm{E}-03$ & $3.24 \mathrm{E}-03$ & $4.24 \mathrm{E}-03$ & $2.08 \mathrm{E}-03$ & $2.87 \mathrm{E}-03$ \\
\hline Fine particulate matter formation & $\mathrm{kg} \mathrm{PM} 2.5$ eq & $2.41 \mathrm{E}+00$ & $5.83 \mathrm{E}-01$ & $2.87 \mathrm{E}+00$ & $6.24 \mathrm{E}-01$ & $2.24 \mathrm{E}+00$ & $4.91 \mathrm{E}-01$ \\
\hline Water consumption & $\mathrm{m} 3$ & $1.03 \mathrm{E}+04$ & $1.67 \mathrm{E}+03$ & $7.53 \mathrm{E}+03$ & $1.22 \mathrm{E}+03$ & $9.80 \mathrm{E}+03$ & $1.59 \mathrm{E}+03$ \\
\hline
\end{tabular}

Source: Adaptation of the results generated in the OpenLCA Software, 2020

Only in the "Global Warming" category the results found by applying the two methodologies presented similar values. This was because $\mathrm{CO}_{2}$ emissions represented about $95 \%$ of the impacts caused in this category and the characterization factors used for this emission are the same in both methodologies. In the other categories, the characterization factors used for the main pollutants are different.

\subsubsection{Normalization Factors}

As shown in Fig. 5, when comparing the relative values of the RECIPE methodology impact categories that coincide with those used by the ILCD methodology, it was found that all categories presented values very close in 
their percentage representation for the three sealing systems. This fact indicates that the analysis may be less sensitive to the uncertainties generated by the choice of the method and its normalization factors.

Fig.5 - Sensitivity analysis of the methodology normalization factor

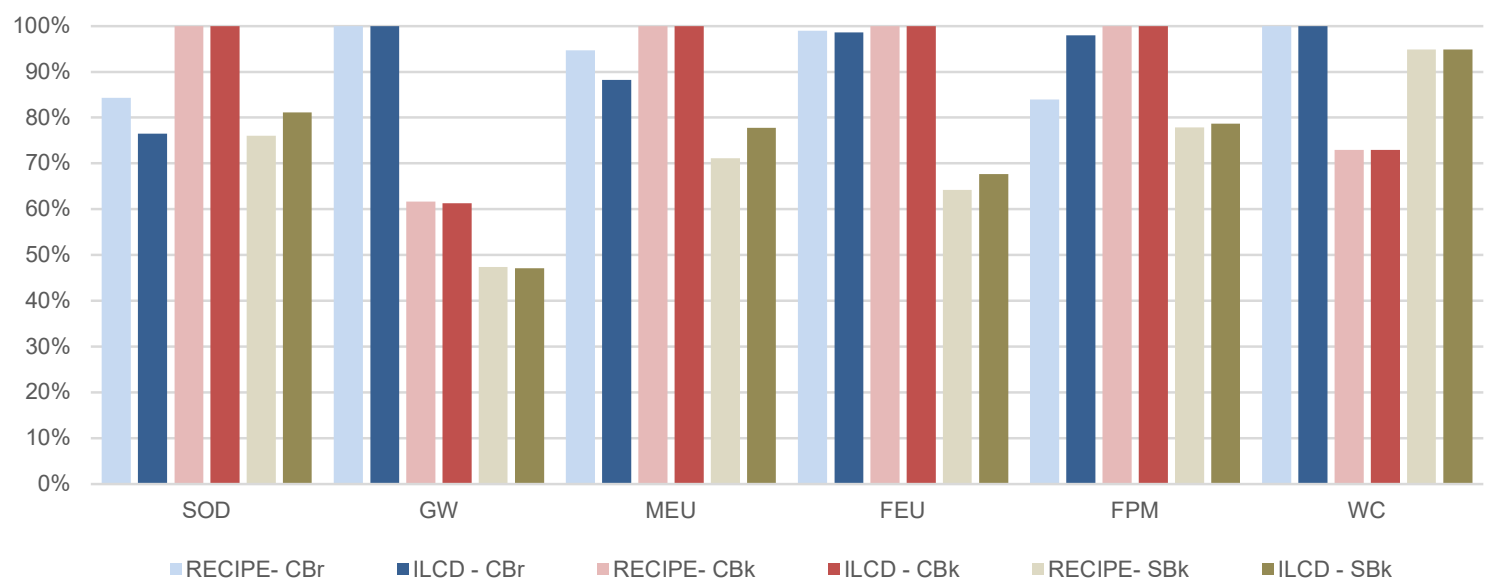

Source: Adaptation of the results generated in the OpenLCA Software, 2020

However, despite being relatively similar, the absolute values of the impacts obtained through the two methodologies differ for all four areas of interest. This is possibly due to differences in the values of the normalization coefficients used by the methodologies. As can be seen in Table 12, the results obtained by the ILCD methodology are much higher than those obtained by the ReCiPe methodology.

Table 12 - Sensitivity analysis of normalization factors

\begin{tabular}{lcccccc}
\multicolumn{1}{c}{ Áreas de proteção } & $\begin{array}{c}\text { RECIPE- } \\
\text { CBr }\end{array}$ & $\begin{array}{c}\text { ILCD } \\
\text { CBr }\end{array}$ & $\begin{array}{c}\text { RECIPE- } \\
\text { CBk }\end{array}$ & $\begin{array}{c}\text { ILCD - } \\
\text { CBk }\end{array}$ & $\begin{array}{c}\text { RECIPE- } \\
\text { SBk }\end{array}$ & $\begin{array}{c}\text { ILCD - } \\
\text { SBk }\end{array}$ \\
\hline Resources Scarcity & $2.66 \mathrm{E}+00$ & $2.05 \mathrm{E}+01$ & $2.89 \mathrm{E}+00$ & $1.50 \mathrm{E}+01$ & $1.98 \mathrm{E}+00$ & $1.95 \mathrm{E}+01$ \\
\hline Damage to human health & $7.51 \mathrm{E}-03$ & $2.13 \mathrm{E}+00$ & $5.51 \mathrm{E}-03$ & $1.71 \mathrm{E}+00$ & $4.25 \mathrm{E}-03$ & $1.29 \mathrm{E}+00$ \\
\hline Damage the diversity of the ecosystem & $1.98 \mathrm{E}-05$ & $1.95 \mathrm{E}+00$ & $1.32 \mathrm{E}-05$ & $1.56 \mathrm{E}+00$ & $1.02 \mathrm{E}-05$ & $1.21 \mathrm{E}+00$ \\
\hline Water consumption & $2.31 \mathrm{E}-02$ & $2.05 \mathrm{E}+01$ & $1.68 \mathrm{E}-02$ & $1.50 \mathrm{E}+01$ & $2.19 \mathrm{E}-02$ & $1.95 \mathrm{E}+01$ \\
\hline Source: Adaptation of the results generated in the OpenLCA Software, 2020 & & &
\end{tabular}

\section{CONCLUSION}

Through the LCA methodology, it was possible to compare the environmental impacts of three vertical sealing systems: CBr, CBk e SBk. It was concluded that SBk presented as the best choice for use in buildings, since it has less environmental impact to the "Resource Scarcity", "Damage to Human Health", and "Damage to the diversity of Ecosystems" interesting areas.

This performance is directly related to the use of cement CPIII type, with $70 \%$ of replacement of clinker by blast furnace slag for the production of concrete blocks, and due the lower consumption of mortar and concrete in the structural masonry system in comparison with the two others.

By the fact of the Brazilian energy matrix be mainly composed of energy from hydroelectric and the greater demand for energy for the production of ceramic and structural blocks, CBr and SBk obtained underperformed to the $\mathrm{CBk}$ in the "Water Consumption" interest area.

The authors of this study had, à priori, the clear idea that concrete blocks would have a greater environmental impact on its life cycle compared to ceramic blocks, due to the high energy demand and high $\mathrm{CO}_{2}$ emission from the calcination process of limestone and clay for the production of clinker. However, as seen it can be seen by the results, that idea do not correspond to the reality for this specific case study, which reinforces the need for implementation of LCA methodology on a case-by-case basis, considering different energy matrices, inputs, distances and other local modes of transport. 
It is worth mentioning that the scenario considered in this study involves a small building and therefore, the results may be different if the study considers a larger number of buildings, a larger building, or even the use of common Portland cement for the manufacture of concrete, mortar and blocks.

Furthermore, the sensitivity analysis of the characterization and normalization factors performed by comparing the results obtained by applying the ReCiPe 2016 methodology with the results of the ILCD Midpoint + methodology proved the robustness of this study, as it indicated that the analysis was less sensitive to the uncertainties generated by the choice of method and its normalization factors The LCA performed in this work is a consistent theoretical framework, capable of assisting technicians and managers in the decision-making process in the construction industry, regarding the choice of the least aggressive construction method for the impact categories analyzed.

In addition, through this study, a complete, consistent and updated database (LCI) was provided on the inputs and outputs of each process that is part of the three most common vertical closure systems in construction sites in Brazil, considering the stages of manufacture, transport and construction. The information, assumptions, formulas, routes for waste management and analysis models used in this work may serve as a reference for conducting future studies using the LCA methodology, helping to densify the literature in this research area.

\section{DECLARATION OF CONFLICTING INTERESTS}

The authors declared no potential conflicts of interest with respect to the research, authorship, and/or publication of this article.

\section{FUNDING}

The authors received no financial support for the research, authorship, and/or publication of this article.

\section{REFERENCES}

ABCP, Associação Brasieleira de Cimento Portland. Fabricação. Disponível em: <https://www.abcp.org.br/cms/basico-sobre-cimento/fabricacao/fabricacao/>. Acesso em: 5 jun. 2019.

ABNT, Associação brasileira de Normas Técnicas. NBR 16697: Cimento Portland - Requisitos. 2018, Rio de Janeiro: ABNT, 2018. p. 12.

ABNT, Associação brasileira de Normas Técnicas. NBR 8545: Execução de alvenaria sem função estrutural de tijolos e blocos cerâmicos. 1984, Rio de Janeiro: ABNT, 1984. p. 13.

ANSAH, Mark Kyeredey et al. An integrated life cycle assessment of different façade systems for a typical residential building in Ghana. Sustainable Cities and Society, v. 53, n. June 2019, p. 101974, 2020. Disponível em: <https://doi.org/10.1016/j.scs.2019.101974>.

BACCELI JÚNIOR, Gilberto. Avaliação do processo Industrial da Cerâmica Vermelha na Região do Seridó RN. 2010.541 f. Universidade Federal do Rio Grande do Norte, Natal, RN, 2010.

BRIBIÁN, Ignacio Zabalza; USÓN, Alfonso Aranda; SCARPELLINI, Sabina. Life cycle assessment in buildings: State-of-the-art and simplified LCA methodology as a complement for building certification. Building and Environment, v. 44, n. 12, p. 2510-2520, dez. 2009. Disponível em: $<$ https://linkinghub.elsevier.com/retrieve/pii/S0360132309001188>.

BUYLE, Matthias; BRAET, Johan; AUDENAERT, Amaryllis. Life cycle assessment in the construction sector: A review. Renewable and Sustainable Energy Reviews, v. 26, p. 379-388, 2013. Disponível em: $<\mathrm{http}: / /$ dx.doi.org/10.1016/j.rser.2013.05.001>.

CABEZA, Luisa F. et al. Life cycle assessment (LCA) and life cycle energy analysis (LCEA) of buildings and the building sector: A review. Renewable and Sustainable Energy Reviews, v. 29, p. 394-416, 2014. Disponível em: $<$ http://dx.doi.org/10.1016/j.rser.2013.08.037>. 
CAMILlo, Luciana Dimas. Proposição de melhorias do desempenho ambiental do processo de produção do aço líquido. 2016. 133 f. Universidade de São Paulo, São Paulo, 2016. Disponível em: $<$ http://www.teses.usp.br/teses/disponiveis/3/3137/tde-12122016-142730/pt-br.php>.

CAYS, John. Life-Cycle Assessment: Reducing Enviromental Impact Risk with Workflow Data You Can Trust. Architectural Design, v. v.87, p. 96-103, 2017.

CBCA, Centro Brasileiro de Construção em Aço. Estatísticas. Disponível em: <http//www.cbca-acobrasil.org.br>. Acesso em: 4 maio 2019.

CNI, Confederação Nacional da Industria. Água, industia e sustentabilidade. . Brasília: [s.n.], 2013. Disponível em: <http://www.portaldaindustria.com.br/cni/canais/cni-sustentabilidade/>.

CONDEIXA, Karina; HADDAD, Assed; BOER, Dieter. Life Cycle Impact Assessment of masonry system as inner walls: A case study in Brazil. Construction and Building Materials, v. 70, p. 141-147, nov. 2014. Disponível em: <http://dx.doi.org/10.1016/j.conbuildmat.2014.07.113>.

CONTRAN, Conselho Nacional de Transito. Requisitos técnicos mínimos para a fiscalização da velocidade de veículos automotores, reboques e semirreboques, conforme o Código de Trânsito Brasileiro. . Brasil: [s.n.]. , 2011

COSTA, Luiz Cláudio. Processo de Fabricação do Coque. Apostila Como Parte do Curso de Carvão Aplicado à Fabricação do Coque de Alto Forno. . Belo Horizonte: Associação Brasileira de Metalurgia, Materiais e Mineração. , 2013

DING, Tao; XIAO, Jianzhuang. Estimation of building-related construction and demolition waste in Shanghai. Waste Management, v. 34, n. 11, p. 2327-2334, nov. 2014. Disponível em: $<$ http://dx.doi.org/10.1016/j.wasman.2014.07.029>.

EVANGELISTA, Patrícia P.A., et al. Environmental performance analysis of residential buildings in Brazil using life cycle assessment (LCA). Construction and Building Materials. v. 169, p. 748-761, 2018.

HUIJBREGTS, Mark A. J. et al. ReCiPe2016: a harmonised life cycle impact assessment method at midpoint and endpoint level. The International Journal of Life Cycle Assessment, v. 22, n. 2, p. 138-147, 12 fev. 2017. Disponível em: <http://dx.doi.org/10.1007/s11367-016-1246-y>.

IBGE, Instituto Brasileiro de Geografia e Estatística. População no último censo.2010. Disponível em: $<$ tps://cidades.ibge.gov.br/brasil/mg/belo-horizonte/panorama>. Acesso em: 22 out. 2020.

ISO, International Organization for Standardization. ISO 14040: Environmental Management - Life Cycle Assessment - Principles and Framework. 2006, [S.1.]: ISO, 2006. p. 20.

ISO, International Organization for Standardization. ISO 14044: Environmental Management - Life Cycle Assessment - Requirements And Guidelines, 2006.

KLÜPFFER, Walter. Environmental life cycle analysis. The International Journal of Life Cycle Assessment, v. 3, n. 5, p. 280-280, set. 1998. Disponível em: <http://link.springer.com/10.1007/BF02979836>.

MAODUS, Nikola et al. Life cycle and energy performance assessment of three wall types insouth-eastern Europe region. Energy and Buildings. v. 133, p. 605-614, 2016.

MAHECHA, Rosa Esperanza González et al. Constructive systems for social housing deployment in developing countries: A case study using dynamic life cycle carbon assessment and cost analysis in Brazil. Energy and Buildings. v. 227, p. 110-395, 2020.

MERAL, Cagla; PASAOGLU, Ozgur; OZCELIK, Gokce. Life-Cycle Assessment of a Basic External Drywall System in Turkey. 11th International Congress on Advances in Civil Engineering. Istanbul, Turkey: [s.n.]. , 2014

NORTON, F.H. Introdução à Tecnologia Cerâmica. 1ª Edição ed. São Pualo: Edgar Blucher, 1973.

NOVO, Ana Luiza Andrade. Perspectivas para o Consumo de Combustivel no Transporte de Carga no Brasil: 
uma Comparação entre os Efeitos Estrutura e Intensidade no Uso Final de Energia do Setor. $2016.180 \mathrm{f}$. Universidade Federal do Rio de Janeiro, Rio de Janeiro, 2016.

PEDRO, Queli Cunha de Lima et al. Geração De Resíduos Na Construção Civil : Comparativo Entre Edificação De Bloco Estrutural E Convencional. Journal of Exact Sciences, v. 19, n. n.1, p. 5-12, 2018.

PINI. TCPO, Tabelas de Composições de Preços para Orçamentos. . São Paulo: Editora Pini Ltda. , 2010

RUSSELL-SMITH, Sarah V. et al. Sustainable target value design: Integrating life cycle assessment and target value design to improve building energy and environmental performance. Journal of Cleaner Production, v. 88, p. 43-51, 2015. Disponível em: <http://dx.doi.org/10.1016/j.jclepro.2014.03.025>.

SEBRAE, Serviço Brasileiro de Apoio ás Micro e Pequenas Empresas. Cerâmica vermelha vermelha para construção: Telhas, tijolos e tubos - Relatório completo. . São Paulo: [s.n.], 2008.

SOUST-VERDAGUER, B.; LlATAS, C.; MOYA, L. Comparative BIM-based Life Cycle Assessment of Uruguayan timber and concrete-masonry single-family houses in design stage. Journal of Cleaner Production, v. 277, p. 121958, 2020. Disponível em: <https://doi.org/10.1016/j.jclepro.2020.121958>.

SOUZA, Danielle Maia De et al. Comparative life cycle assessment of ceramic brick, concrete brick and cast-inplace reinforced concrete exterior walls. Journal of Cleaner Production, v. 137, p. 70-82, nov. 2016. Disponível em: <http://dx.doi.org/10.1016/j.jclepro.2016.07.069>.

SOUZA, Danielle Maia De et al. Comparative Life Cycle Assessment of ceramic versus concrete roof tiles in the Brazilian context. Journal of Cleaner Production, v. 89, p. 165-173, 2015. Disponível em: $<$ http://dx.doi.org/10.1016/j.jclepro.2014.11.029>.

VILVENTHAN, Aneetha; RAM, VG; SUGUMARAN, S. Value stream mapping for identification and assessment of material waste in construction: A case study. Waste Management \& Research, v. 37, n. 8, p. 815-825, 19 ago. 2019. Disponível em: <http://journals.sagepub.com/doi/10.1177/0734242X19855429>.

WOLF, Marc-Andree et al. The International Reference Life Cycle Data System (ILCD) Handbook - Towards more sustainable production and consumption for a resource-efficient Europe. Luxembourg: Publications Office of the European Union, 2012.

WORLDSTEEL. Sustainable Steel. At the core of a green economy. . Bruxelas, Bélgica: [s.n.], 2012. Disponível em: <https:/www.worldsteel.org/en/dam/jcr:5b246502-df29-4d8b-92bb-afb2dc27ed4f/Sustainable-steel-at-thecore-of-a-green-economy.pdf $>$. 


\section{APPENDIX A}

Fig. A1 - Ground floor

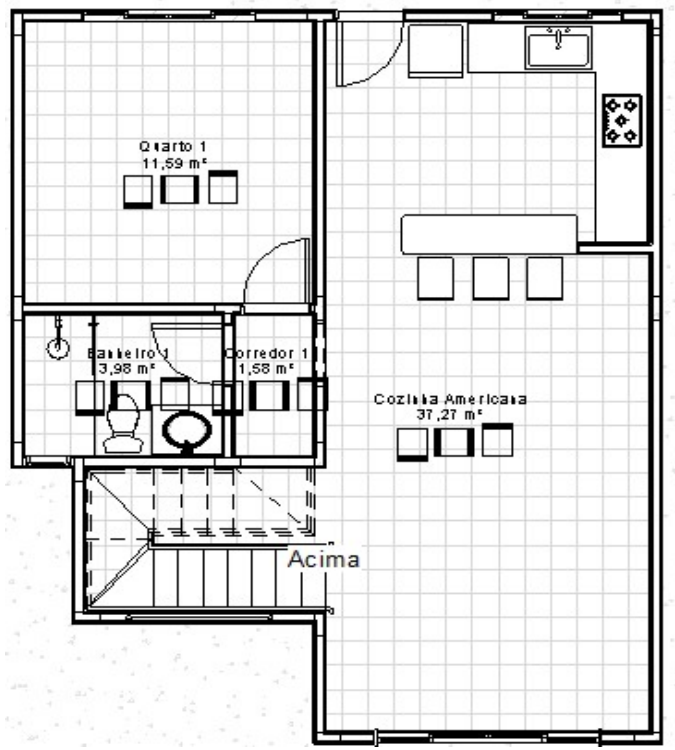

Source: Prepared by the authors, 2020.
Fig. A2 - Second floor

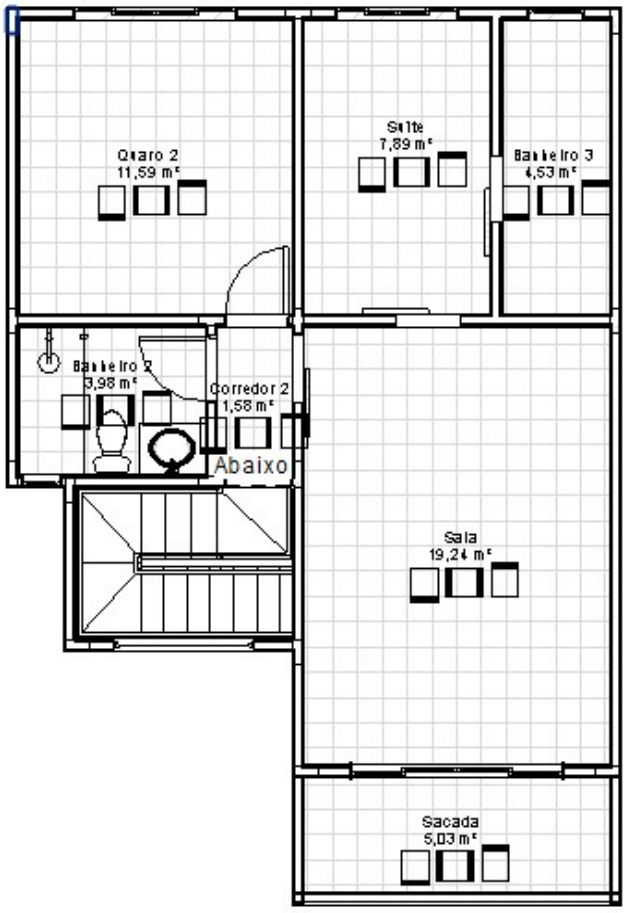

Source: Prepared by the authors, 2020. 


\section{APPENDIX B}

Fig.B1. Inputs and outputs of the one square meter production of with ceramic brick the system

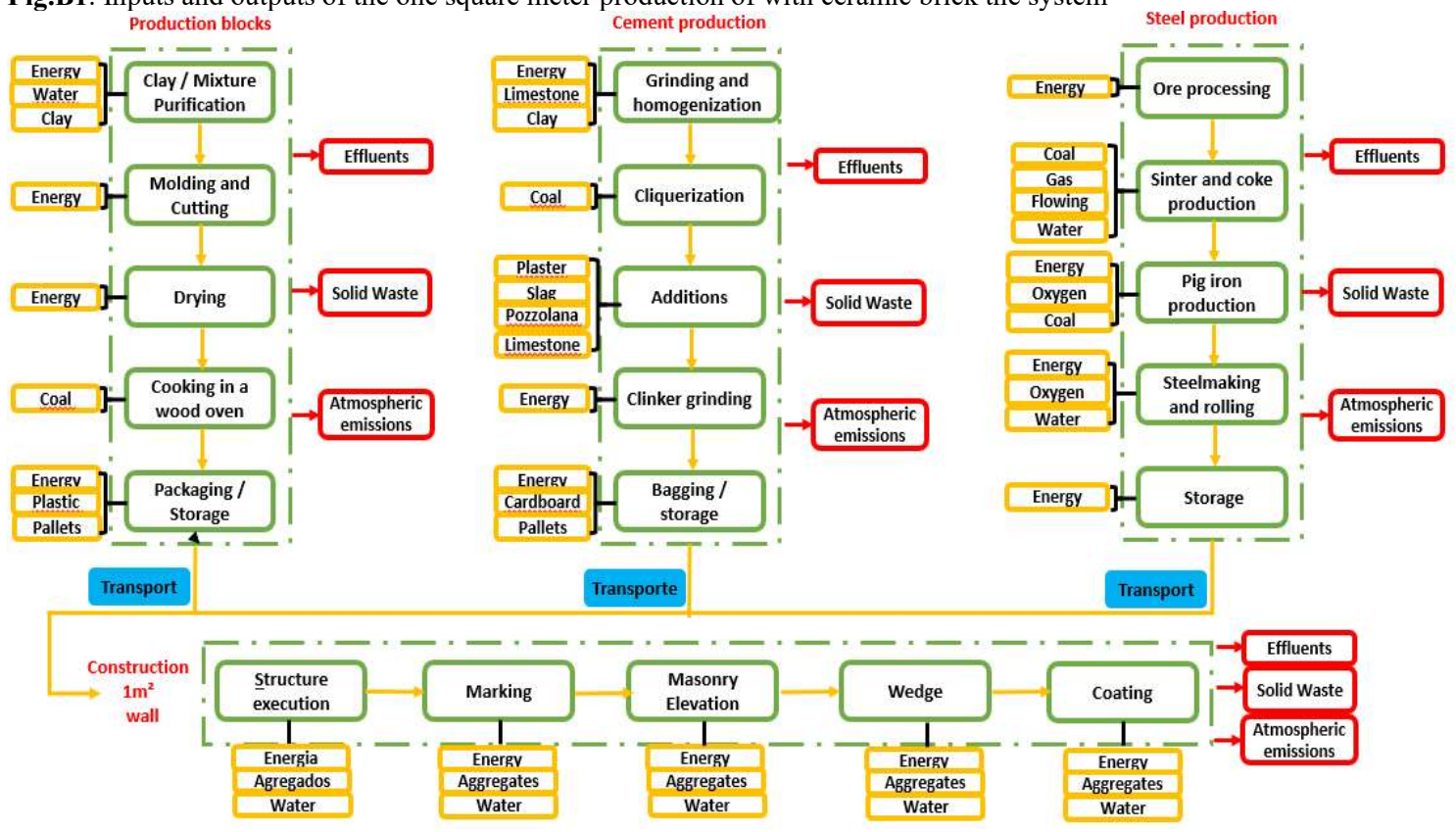

Source: Prepared by the authors, 2020.

Fig.B2. Inputs and outputs of the one square meter production of with concrete block the system

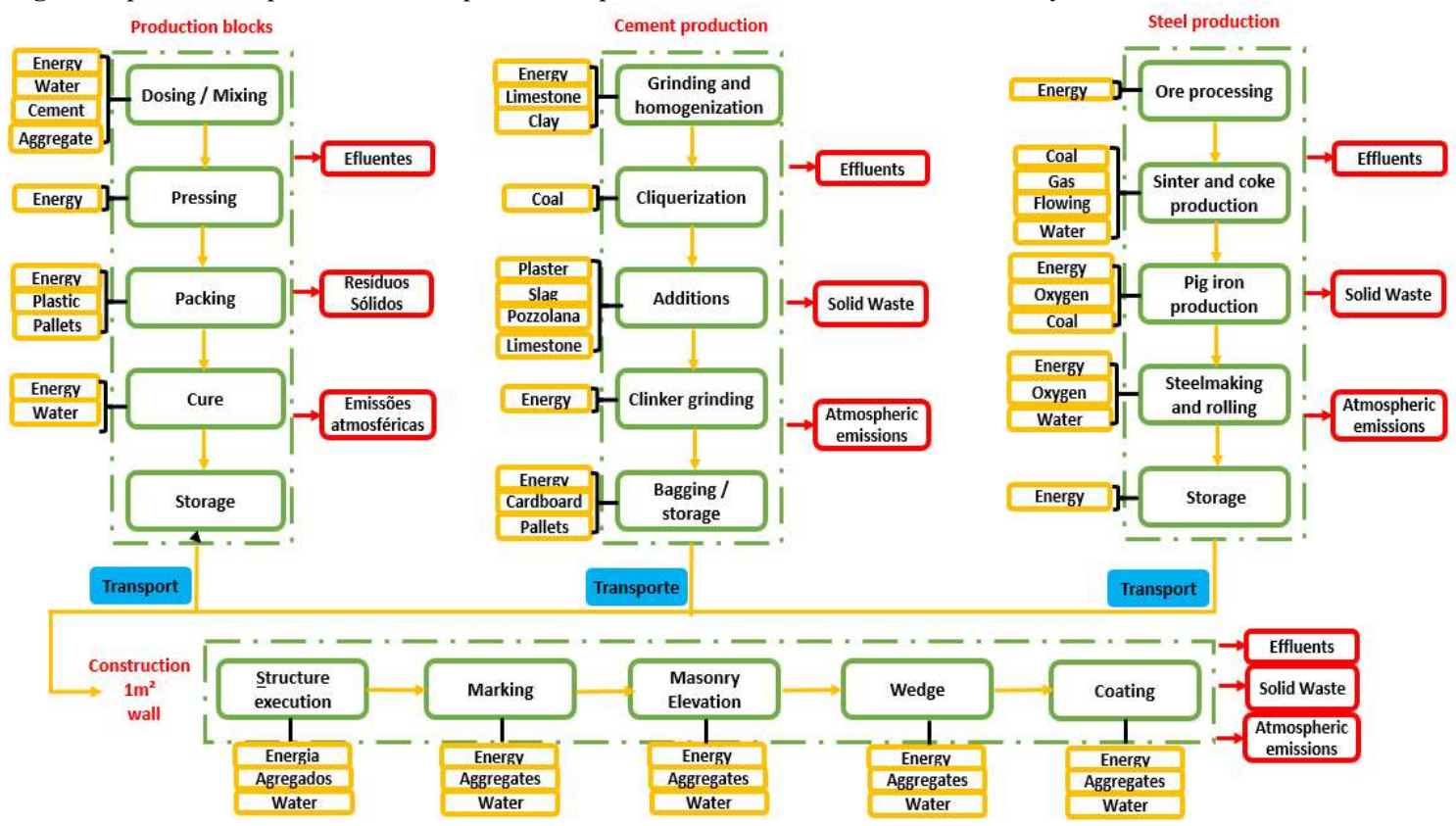

Source: Prepared by the authors, 2020. 
Fig.B3. Inputs and outputs of the one square meter production of the structural block system
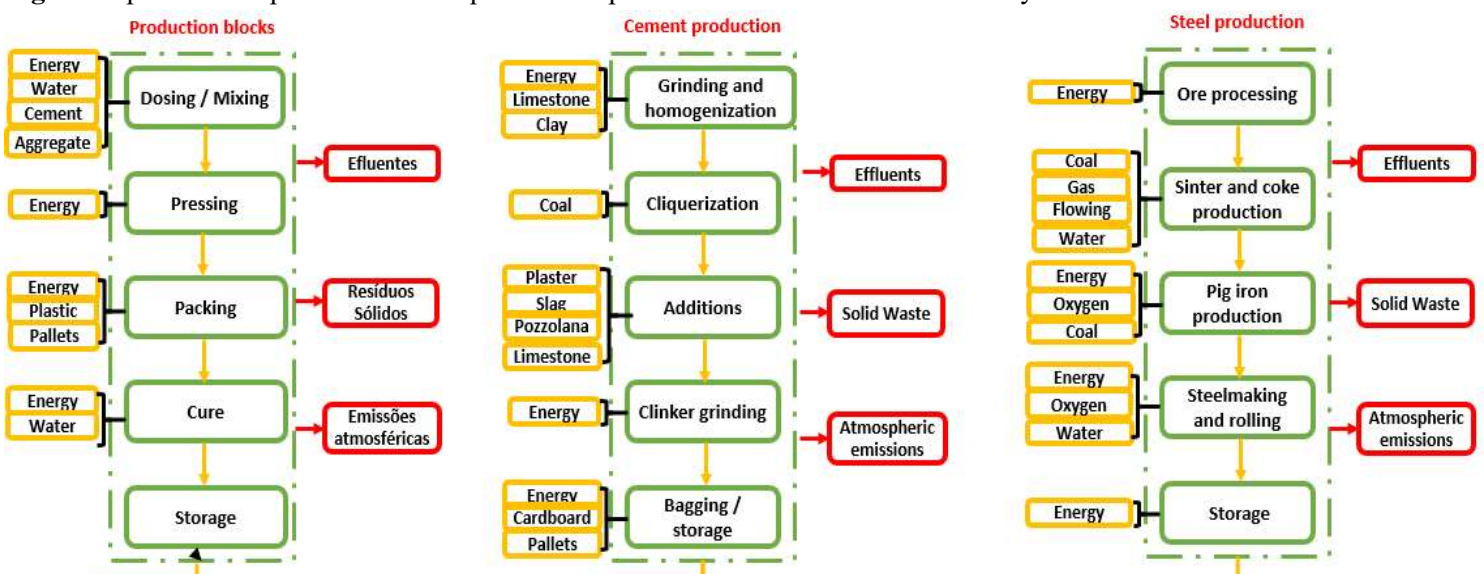

Transport

Transport

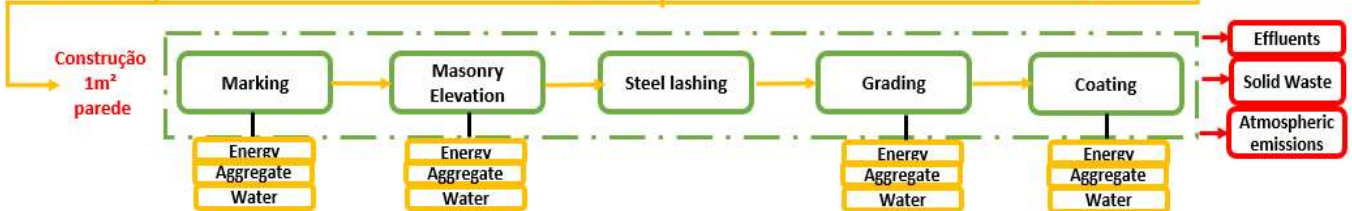

Source: Prepared by the authors, 2020 . 